\title{
Utilization of Landsat Images for Identification and Analysis of Changes in the Mangrove Forest Area in East Aceh District
}

\author{
Ayu Suciani ${ }^{1}$, M Taufik Rahmadi $^{2}$, M Ridha Syafii Damanik ${ }^{3}$, Ali Nurman ${ }^{4}$ \\ \{ayusuciani@unsam.ac.id ${ }^{1}$, taufikrahmadi@unimed.ac.id ${ }^{2}$, mridhadamanik@unimed.ac.id ${ }^{3}$ \} \\ ${ }^{1}$ Geography Education Department, Samudra University, Langsa, Indonesia \\ ${ }^{2,3,4}$ Geography Education Department, Universitas Negeri Medan, Indonesia
}

\begin{abstract}
Mangroves are one of the plants that live in coastal areas and have functions and benefits for the surrounding ecosystem. This study aims to examine the accuracy of Landsat 8 OLI's imagery in mapping spatial distribution, analyzing changes in the area, and factors that affect changes in the mangrove forest area in East Aceh District. This study consists of geometric corrections, radians, reflectance, atmosphere, and using the maximum likelihood classification. The results of this study include (1) the level of accuracy of Landsat imagery in mapping the distribution of mangroves in East Aceh Regency was $70.3 \%$, (2) mangroves in East Aceh District experienced a reduction in area of 45099.58 Ha over 22 years, (3) changes are caused by high temperatures of mangrove waters and human activities in utilizing mangroves
\end{abstract}

Keywords: Landsat 8 OLI, mangrove, change factor, East Aceh District

\section{Introduction}

Indonesia is one of the regions in the world that has the largest mangrove forest resources and is spread in various coastal areas that are still affected by tides. In tropical and subtropical areas mangrove forests have a very important function in protecting coastal areas from erosion and maintaining hydrological functions in the region (Haryani, 2013). East Aceh Regency is one area that has mangrove forests. The condition of mangrove forests in East Aceh experiences significant changes every year caused by natural factors (temperature, $\mathrm{pH}$ levels, salinity) and human factors (mangrove logging). According to Habadaily (2015), mangrove forests in the coastal areas of East Aceh were cut down by many people to make charcoal. Changes in the extent of mangrove forests will affect the function of mangrove forests as guardians of erosion of coastal areas, buffer zones, and breeding grounds for other aquatic ecosystems.

Changes in mangrove forests can be identified using remote sensing technology and data. Remote sensing has the advantage of temporal resolution, without direct contact with objects, and can reach large areas. This study uses remote sensing data on Landsat 8 OLI imagery and aims to analyze the accuracy of Landsat imagery and the factors that affect changes in the extent of mangrove forests in East Aceh District. 


\section{Method}

The research was conducted from September to October 2019 which is located at $4^{\circ} 37$ "LU - $97^{\circ} 37^{\prime \prime}$ BT. For more details, the study area can be seen in Figure 1 below.

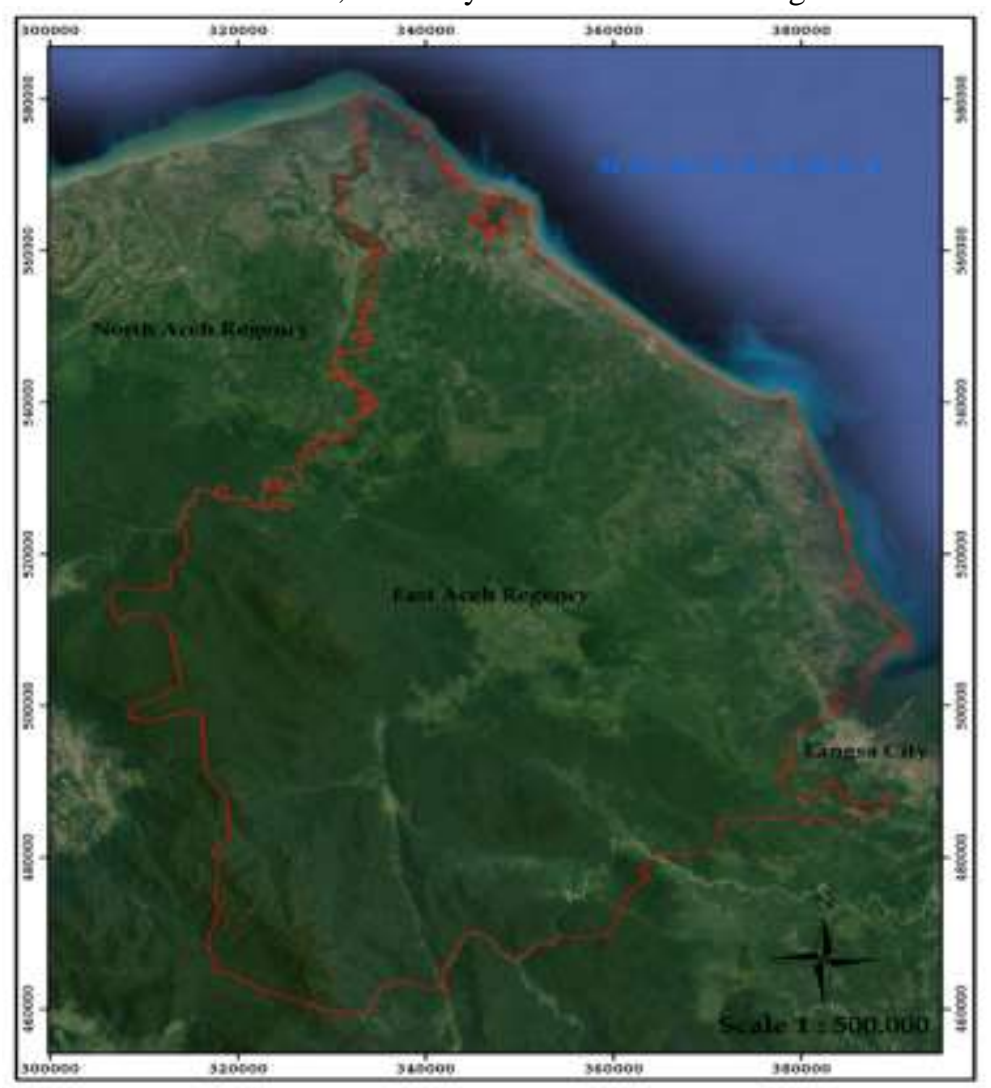

Fig. 1. Image of the Research Area

The data used in this study are Landsat 8 OLI imagery recording in 1996, 2006, 2016, and 2018, temperature data, and water $\mathrm{pH}$ data. This research was conducted in several stages, namely (1) image data processing consisting of geometric corrections, radians, reflectance, atmospheres, and multispectral classification, (2) field surveys based on tentative maps to test the accuracy of the image and the collection until the field, (3) test image accuracy based on the results of the field survey using the confusion matrix table method, and (4) image reinterpretation. The results of the study consisted of the accuracy of Landsat 8 OLI imagery and the factors that influenced the change in the mangrove area in East Aceh District. 


\section{Results and discussion}

The map accuracy test in this study uses confusion matrix tables. Based on the results of accuracy testing on the distribution map of mangrove forests in East Aceh Regency in 2018 produced an accuracy rate of $70.3 \%$. According to Green et al. (2000) mapping accuracy values between $60 \%,-80 \%$ can be used for inventory activities for resource monitoring. The mapping of the mangrove forest area in East Aceh Regency was obtained based on the results of the multispectral classification algorithm maximum likelihood. The channels/bands used in the classification are channels/bands 5,4,2 in Landsat 5 and channels/bands 6,5,3 in Landsat 8 OLI. The choice of channel/band is because it gives a clear appearance to the object image. For more details, the extent of changes in mangrove forests can be seen in Table 1 and Figure 2 below.

Table 1. Distribution of area and change of mangrove forest East Aceh Regency

\begin{tabular}{cccc}
\hline No & Year & Mangrove Forest Area (Ha) & Changes in Area (Ha) \\
\hline 1. & 1996 & 65539.44 & 0 \\
2. & 2006 & 100714.68 & $(+) 35175.24$ \\
3. & 2016 & 94108.05 & $(-) 84036,37$ \\
4. & 2018 & 97869.6 & $(+) 3761.55$ \\
\hline
\end{tabular}

Source: Digital Image Processing (2019)

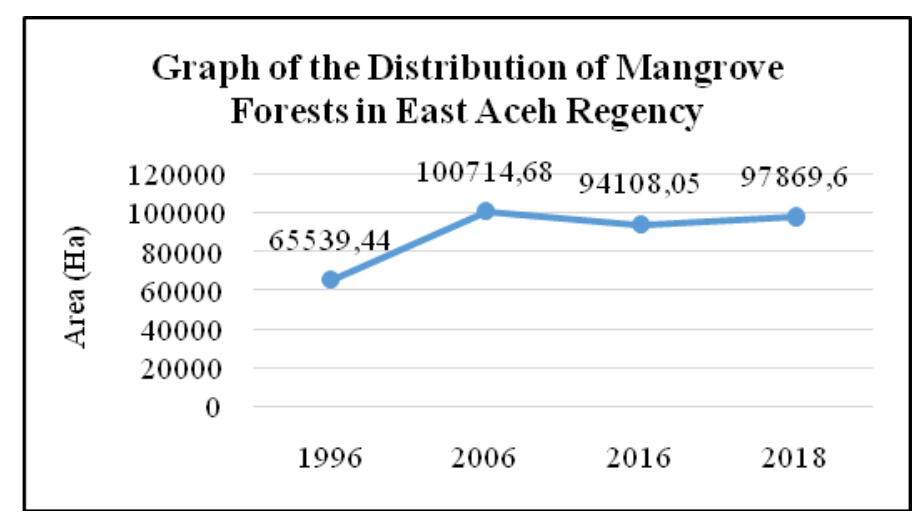

Fig. 2. Changes in the Extent of Mangrove Forest Ecosystem East Aceh Regency

Based on the data in Table 1 and Figure 2, it can be seen the change in the area of mangrove forests from 1996 - 2018. From 1996 to 2006 there was an increase in the area of mangrove forests amounting to $35175.24 \mathrm{Ha}$. From 2006 to 2016 there was a reduction in the area of mangrove forests by $84036.37 \mathrm{Ha}$. From 2016 to 2018 there has been an increase in the area of mangrove forests by $3761.55 \mathrm{Ha}$. For more details on changes in the area of mangrove forests in East Aceh Regency within 22 years can be seen in Figure 3 below. 


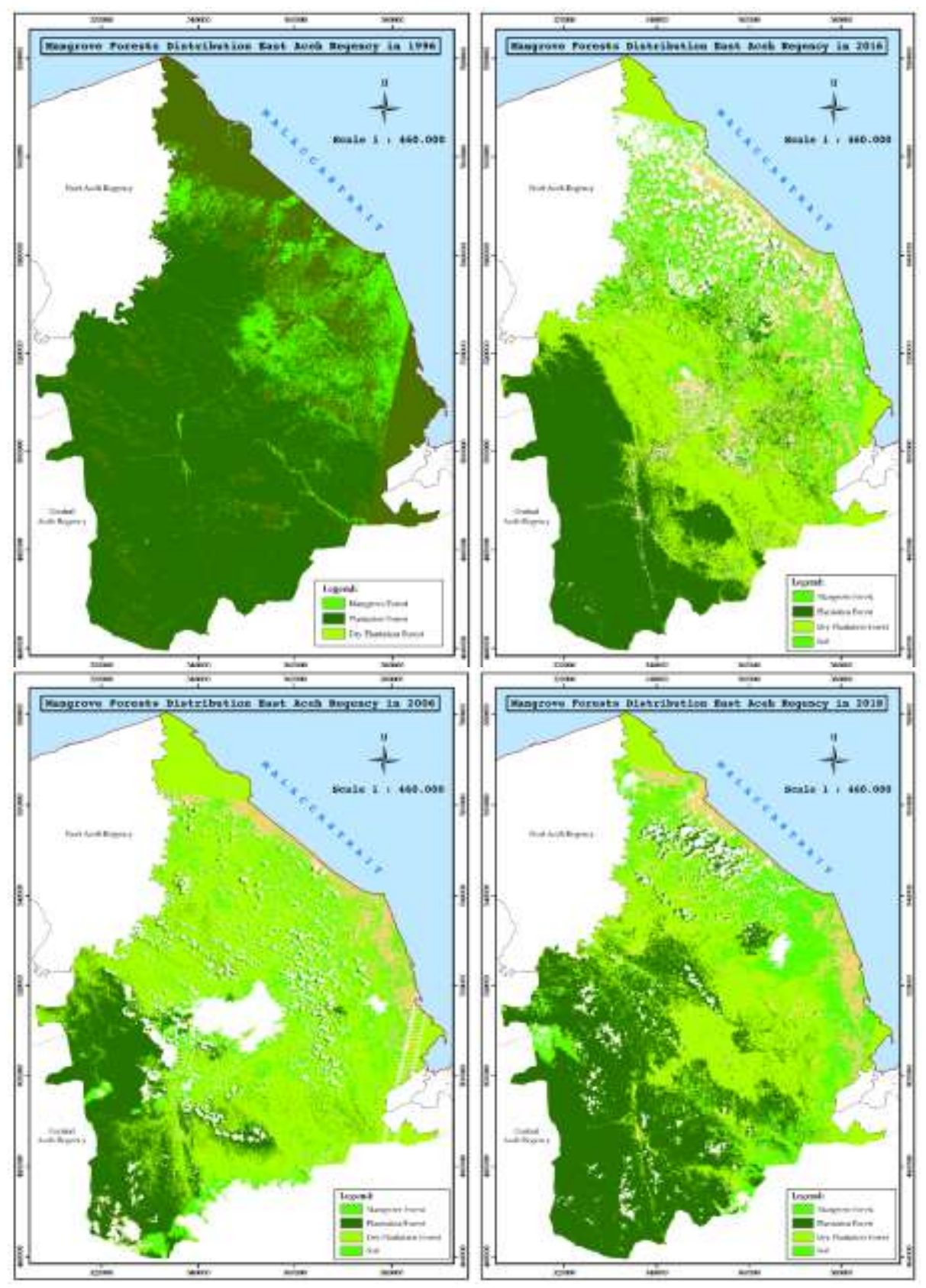

Fig. 3. map of changes in the extent of mangrove forests in 1996, 2006, 2016, and 2018 
Changes in the area of mangrove forests can occur due to various sustainability factors, namely natural factors such as temperature, $\mathrm{pH}$, salinity, oxygen levels and human factors such as mangrove logging and other human activities. This study only discusses natural factors (temperature and $\mathrm{pH}$ ) that cause changes in the distribution of mangrove forests in East Aceh District. Temperature is one of the important factors in the growth of mangrove forests exocytes. According to Minister of Environment Decree No. 51 of 2014 concerning seawater quality standards, mangrove forests have a temperature tolerance value between $280 \mathrm{C}-320 \mathrm{C}$. Based on the results of the field survey by taking as many as 24 points, the research location has a minimum temperature of $31.20 \mathrm{C}$, a maximum temperature of $35.40 \mathrm{C}$, and an average temperature of $32.40 \mathrm{C}$.

The temperature level of this research location exceeds the temperature level that can be tolerated by mangroves so that the death of mangroves can occur more quickly. This high temperature is caused by various factors namely the effect of climate change, imbalance of energy received by the surface of the water, and heat exchange between the water and the surrounding air. For more details, the temperature level at the study site can be seen in Figure 4 below.

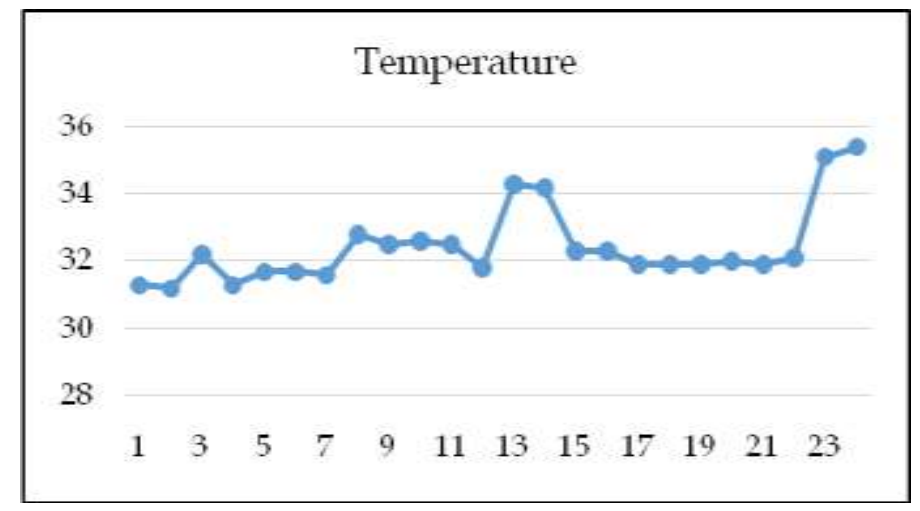

Fig. 4. The temperature graph at the study site

$\mathrm{pH}$ is the degree of acidity used to measure the acidity and basicity of a solution. A good water $\mathrm{pH}$ level for mangroves is $7-8.5$ (Kepmen LH, 20054). Water $\mathrm{pH}$ in this study has a minimum $\mathrm{pH}$ value of 7.26, a maximum $\mathrm{pH}$ of 9.07, and an average $\mathrm{pH}$ of 8.09 . The degree of $\mathrm{pH}$ at the sampling location, the maximum $\mathrm{pH}$ value has a degree outside the threshold acceptable to mangroves, while the average and minimum $\mathrm{pH}$ values are still under conditions that can be accepted by mangroves. The high or low $\mathrm{pH}$ level is caused by the concentration of gases in water and the process of decomposition of organic matter in the waters. For more details on the $\mathrm{pH}$ level at the study, the site can be seen in Figure 5 below. 


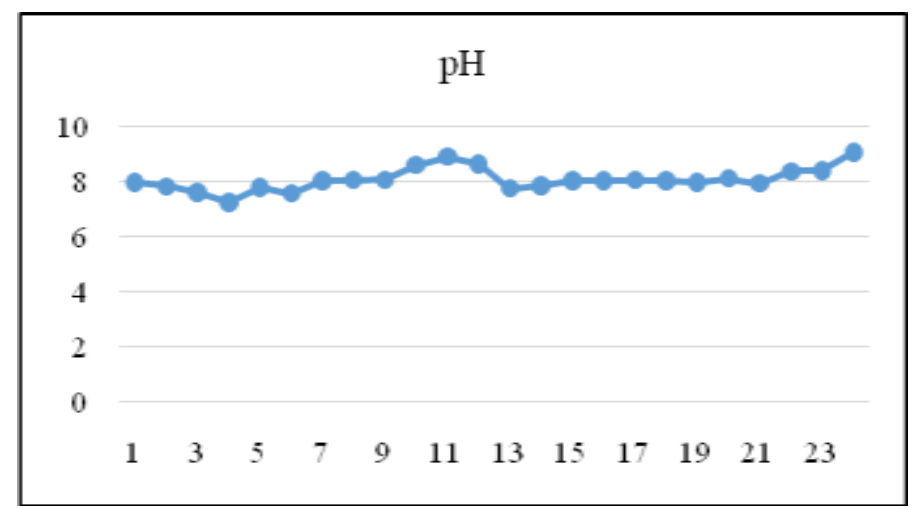

Fig. 5. Graph of a degree of $\mathrm{pH}$ at the study site

\section{Conclusion}

This research gives an accuracy of 70.3\% Landsat image. Changes in the distribution of mangroves need to get more attention given the magnitude of the benefits of mangroves for humans and surrounding ecosystems. The change factor that most influences the change in area is the high temperature in the study area that can be tolerated by mangroves.

\section{References}

[1] Darmawan, A., \& Hilmanto, R. (2014). Perubahan Tutupan Hutan Mangrove di Pesisir Kabupaten Lampung Timur. Jurnal Sylva Lestari, 2(3), 111-124.

[2] Green, E., Mumby, P., Edwards, A., \& Clark, C. (2000). Remote Sensing: Handbook for Tropical Coastal Management. United Nations Educational, Scientific and Cultural Organization (UNESCO).

[3] Haryani, N. S. (2013). Analisis perubahan hutan mangrove menggunakan citra landsat. Jurnal Ilmiah Widya, 4(2).

[4] Hidayah, Z., Wiyanto, D. B., \& Madura, J. I. K. U. T. (2013). Analisa temporal perubahan luas hutan mangrove di kabupaten sidoarjo dengan memanfaatkan data citra satelit. Jurnal Bumi Lestari, 13(2).

[5] Hidup, M. N. L. (2004). Peraturan Menteri Negara Lingkungan Hidup Nomor 10 Tahun 2006 Tentang Baku Mutu Air Limbah Bagi Usaha Dan/Atau Kegiatan Industri Vinyl Chloride Monomer Dan Poly Vinyl Chloride.

[6] Suwargana, N. (2010). Analisis perubahan hutan mangrove menggunakan data penginderaan jauh di Pantai Bahagia, Muara Gembong, Bekasi. Jurnal Penginderaan Jauh dan Pengolahan Data Citra Digital, 5. 